\title{
Using Mobile Phones to Improve Vaccination Uptake in 21 Low- and Middle-Income Countries: Systematic Review
}

Clare Oliver-Williams ${ }^{1,2}$, PhD; Elizabeth Brown ${ }^{3,4}$, BA (Hons); Sara Devereux ${ }^{5,6}$, BA (Hons); Cassandra Fairhead ${ }^{4,7}$, BA (Hons); Isaac Holeman ${ }^{8,9,10}$, MPhil

\footnotetext{
${ }^{1}$ Homerton College, University of Cambridge, Cambridge, United Kingdom

${ }^{2}$ Cardiovascular Epidemiology Unit, Department of Public Health \& Primary Care, University of Cambridge, Cambridge, United Kingdom

${ }^{3}$ Gonville and Caius College, University of Cambridge, Cambridge, United Kingdom

${ }^{4}$ University College London, London, United Kingdom

${ }^{5}$ Trinity College, University of Cambridge, Cambridge, United Kingdom

${ }^{6}$ Queens' College, University of Cambridge, Cambridge, United Kingdom

${ }^{7}$ King's College, University of Cambridge, Cambridge, United Kingdom

${ }^{8}$ Judge Business School, University of Cambridge, Cambridge, United Kingdom

${ }^{9}$ Global Health Academy, University of Edinburgh, Edinburgh, United Kingdom

${ }^{10}$ Medic Mobile, San Francisco, CA, United States
}

\section{Corresponding Author:}

Clare Oliver-Williams, $\mathrm{PhD}$

Cardiovascular Epidemiology Unit

Department of Public Health \& Primary Care

University of Cambridge

Wort's Causeway

Cambridge,

United Kingdom

Phone: 441223748650

Email: cto21@medschl.cam.ac.uk

\section{Abstract}

Background: The benefits of vaccination have been comprehensively proven; however, disparities in coverage persist because of poor health system management, limited resources, and parental knowledge and attitudes. Evidence suggests that health interventions that engage local parties in communication strategies improve vaccination uptake. As mobile technology is widely used to improve health communication, mobile health (mHealth) interventions might be used to increase coverage.

Objective: The aim of this study was to conduct a systematic review of the available literature on the use of mHealth to improve vaccination in low- and middle-income countries with large numbers of unvaccinated children.

Methods: In February 2017, MEDLINE (Medical Literature Analysis and Retrieval System Online), Scopus, and Web of Science, as well as three health organization websites-Communication Initiative Network, TechNet-21, and PATH-were searched to identify mHealth intervention studies on vaccination uptake in 21 countries.

Results: Ten peer-reviewed studies and 11 studies from white or gray literature were included. Nine took place in India, three in Pakistan, two each in Malawi and Nigeria, and one each in Bangladesh, Zambia, Zimbabwe, and Kenya. Ten peer-reviewed studies and 7 white or gray studies demonstrated improved vaccination uptake after interventions, including appointment reminders, mobile phone apps, and prerecorded messages.

Conclusions: Although the potential for mHealth interventions to improve vaccination coverage seems clear, the evidence for such interventions is not. The dearth of studies in countries facing the greatest barriers to immunization impedes the prospects for evidence-based policy and practice in these settings.

(JMIR Mhealth Uhealth 2017;5(10):e148) doi: 10.2196/mhealth.7792

\section{KEYWORDS}

cell phones; vaccination; communication; telemedicine; mHealth; global health 


\section{Introduction}

In 2005, the World Health Organization encouraged member states to take action to incorporate eHealth in health systems and services. The term electronic health (eHealth) refers to the practice of supporting health care through information and communication technologies; eHealth initiatives have been recognized for their potential to strengthen health systems and to improve access to care [1].

The subset of eHealth initiatives that make use of mobile phones or any portable electronic devices with software applications are often discussed using the term mobile health (mHealth). Mobile technologies have been applied to a diverse range of initiatives outlined in recent reviews of mHealth interventions globally [2,3] and in low- and middle-income countries (LMIC) [4]. Given that nearly $100 \%$ of the world's population lives within reach of a mobile phone signal, many regard mHealth initiatives as particularly promising in LMIC, where other forms of communication infrastructure are underdeveloped [4]. In areas where phone ownership among the general population remains relatively low, community health workers can be key players in mHealth. Equipped with mobile phones, they can efficiently and effectively disseminate information, such as clinical updates, learning resources, and reminders, both to other health workers and to patients [5,6].

Various mHealth interventions in LMIC have aimed to improve vaccination uptake by increasing awareness of vaccine availability and providing timely reminders of when they are due. Vaccination averts approximately 2 to 3 million deaths annually and can be highly cost-effective [7]. Disparities in vaccine coverage persist because of limited resources, vaccines stock outs, geographic inaccessibility and long wait times, and poor health system management in general $[8,9]$. Additional demand-side barriers relate to parental knowledge and attitudes, fear of side effects, and conflicting priorities [9]. An estimated 18.7 million infants worldwide did not receive routine vaccinations such as the DPT3 (diphtheria) vaccine in 2014, and over $60 \%$ of these children live in just 10 LMIC. Evidence suggests that top-down communication strategies are detrimental to some vaccination drives in LMIC, whereas interpersonal communication incorporating local leaders and networks and utilizing a wide range of communication channels are more successful [10]. As mobile technology is widely used to improve health communication in general, mHealth interventions might be used to improve vaccine coverage.

Although the potential for mHealth interventions to improve vaccination coverage seems clear, the evidence for such interventions is not. The global population of unvaccinated children is highly concentrated in a small number of countries; as a result, literature reviews of mobile technology for immunization globally, or even of LMIC in general, may be of limited relevance. To the best of our knowledge, there has been no systematic overview of mHealth for immunization programs in countries with the greatest need to improve vaccination coverage. For this reason, the objective of this systematic review was to summarize the outcomes and implementation challenges of mHealth for vaccination interventions, focusing on 21 countries with high proportions of unvaccinated children [11].

\section{Methods}

\section{Data Sources and Search Strategy}

This systematic review was conducted using a predefined protocol and in accordance with the preferred reporting items for systematic reviews and meta-analyses (PRISMA) and meta-analysis of observational studies in epidemiology (MOOSE) checklists (Multimedia Appendices 1 and ). A literature review was conducted on February 23, 2017 (date last searched) using MEDLINE (Medical Literature Analysis and Retrieval System Online), Scopus, and Web of Science databases. Gray and white literature was also identified on the Communication Initiative Network, TechNet-21, and PATH websites. Search terms were grouped into three categories: those relating to vaccination, such as inoculation and immunization; mHealth, for example, mobile phone or telemedicine; and geographical location. No restrictions were placed on language. Details of the search terms are located in Multimedia Appendix 3 . Titles and then abstracts were searched, potentially relevant papers were read, and those that did not meet the predefined inclusion criteria were removed. The inclusion criteria specified the country (Angola, Cambodia, Democratic Republic of the Congo, Ethiopia, India, Indonesia, Iraq, Kenya, Mali, Malawi, Nepal, Niger, Nigeria, Pakistan, the Philippines, Senegal, South Africa, Tanzania, Uganda, Zambia, and Zimbabwe); any form of mhealth (including mobile phone calls, phone apps, text messages, Internet, and email); and an outcome pertaining to vaccination (including uptake of vaccinations, attendance at vaccination appointments, and completeness of vaccination protocol for individuals or for regions). Reference lists of the selected studies and relevant reviews were also searched for additional publications.

\section{Study Selection and Eligibility}

Prospective interventional and observation studies that evaluated mHealth interventions on any part of a vaccination program were of interest if they were based in the relevant countries listed previously. These countries were chosen, as they include the 10 countries where more than $60 \%$ of children were unvaccinated for the final dose of Diphtheria-tetanus-pertussis vaccination as of 2014 [11], in addition to 11 countries that also have low routine vaccination uptake where the authors identified ongoing large-scale mHealth initiatives.

\section{Data Extraction}

Data were extracted by 4 authors and a predesigned data abstraction form was used. Any conflicts over inclusion were resolved by discussion. Relevant information included location, age of participants, study design, numbers included in the study, type of mobile phone intervention and frequency, duration of the study, outcome measures, and results. Where multiple publications from the same study were found, only the most up-to-date or comprehensive information was extracted. 


\section{Risk of Bias}

The quality of peer-reviewed studies was rated for the risk of bias. Randomized control trials (RCTs) were assessed using the Cochrane Collaboration tool [12]. This tool considers seven different scales: random sequence generation, allocation concealment, blinding of participants and personnel, blinding of outcome assessment, incomplete outcome data, selective reporting, and other bias. Observational studies were evaluated using the Newcastle-Ottawa Scale [13], which uses a star system to assess three aspects: participant selection, comparability of study groups, and ascertainment of outcomes. Studies that received a score of nine stars were judged to be at low risk of bias, studies that scored seven or eight stars were medium risk, and those that scored six or less were at high risk.

\section{Analysis}

Descriptive summary tables were constructed to display the results. Due to the small number and heterogeneity of studies identified, it was not possible to either conduct a statistical analysis of the results or assess publication bias through funnel plots.

\section{Results}

\section{Studies Identified}

The literature search identified 23,157 potentially relevant citations. After screening titles and abstracts, 58 peer-reviewed papers remained for further evaluation, and following detailed assessment, a further 48 were excluded (Figure 1). The remaining 10 unique papers, plus 11 studies from the gray and white literature, were included within this review.

\section{Characteristics of Included Studies}

Of the 21 studies fulfilling the inclusion or exclusion criteria, 10 were peer-reviewed, of which 3 were RCTs. Tables 1 and 2 outline the key characteristics of studies included in this review, and Table 3 summarizes geographical locations. The interventions evaluated in these papers ranged from SMS messages sent to families to remind and encourage them to take their children to the health center for vaccinations, to using mobile phones to record which settlements have been covered by vaccination campaigns, to mobile phone apps helping health workers to update and access relevant data to facilitate vaccination campaigns. 
Figure 1. Flowchart for literature search.

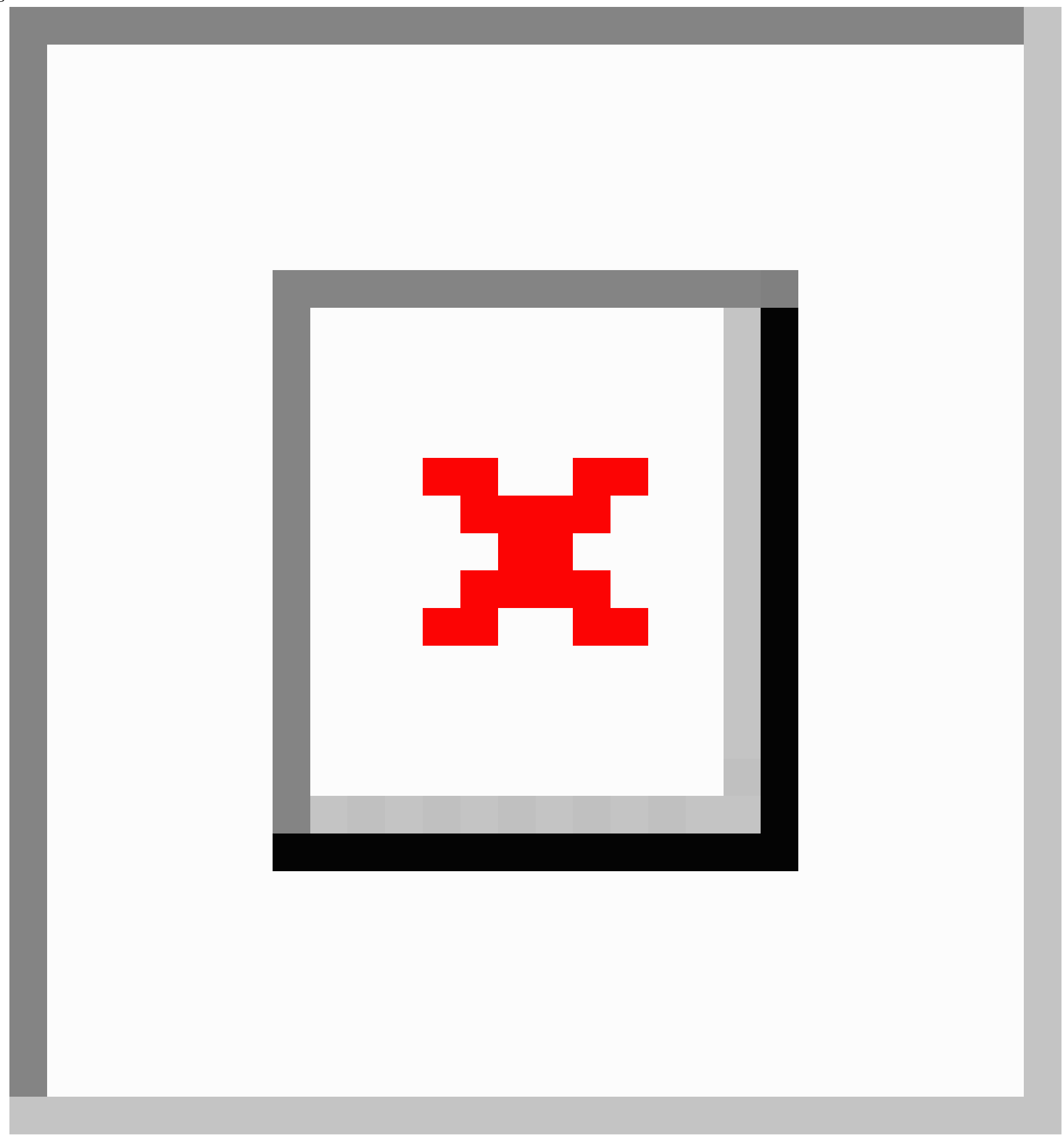


Table 1. Summary of relevant papers from peer-reviewed literature.

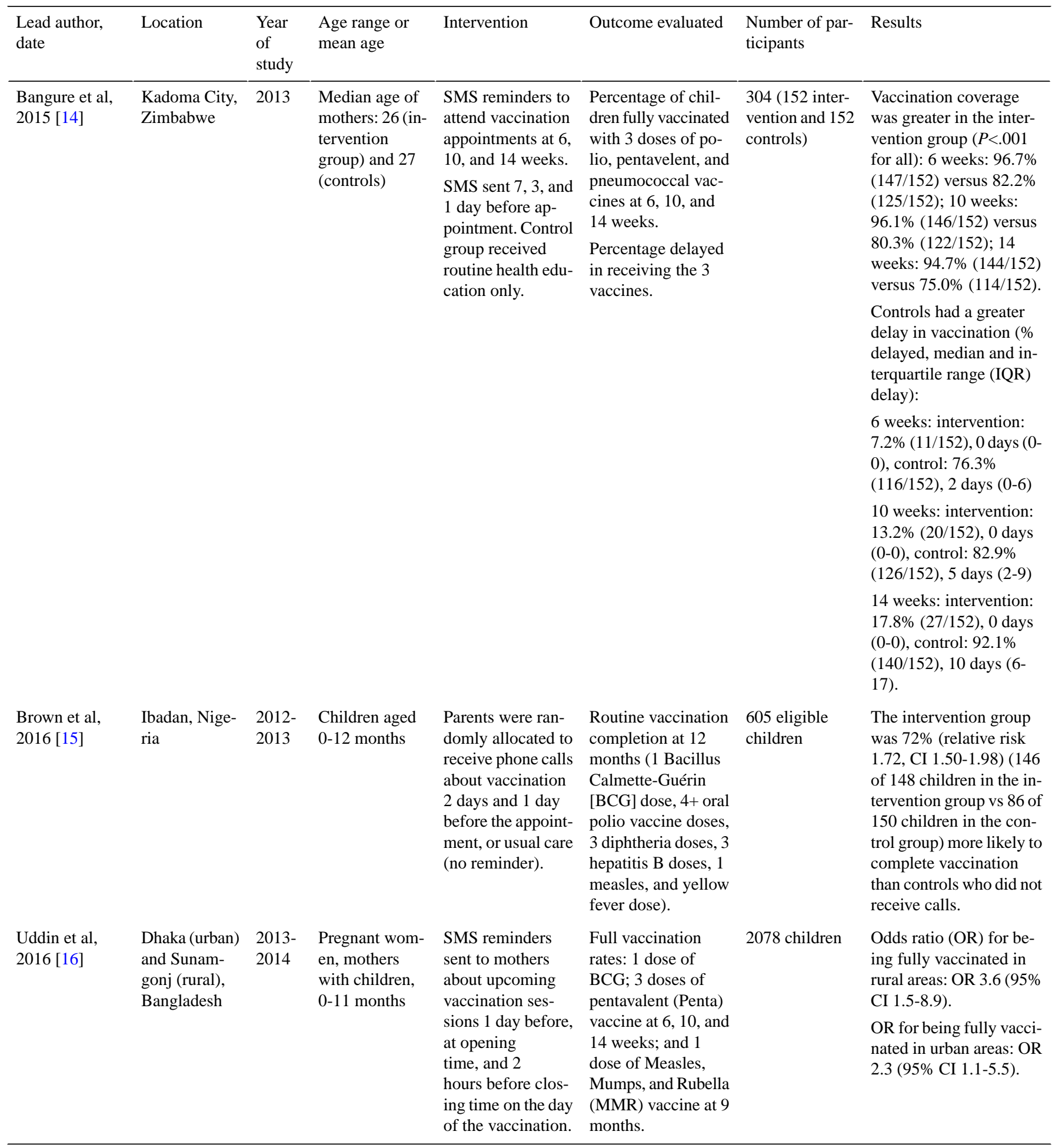




\begin{tabular}{|c|c|c|c|c|c|c|c|}
\hline $\begin{array}{l}\text { Lead author, } \\
\text { date }\end{array}$ & Location & $\begin{array}{l}\text { Year } \\
\text { of } \\
\text { study }\end{array}$ & $\begin{array}{l}\text { Age range or } \\
\text { mean age }\end{array}$ & Intervention & Outcome evaluated & $\begin{array}{l}\text { Number of par- } \\
\text { ticipants }\end{array}$ & Results \\
\hline $\begin{array}{l}\text { Garcia-Dia et } \\
\text { al, } 2016 \text { [17] }\end{array}$ & $\begin{array}{l}\text { Bago City } \\
\text { area, Philip- } \\
\text { pines }\end{array}$ & $\begin{array}{l}2013- \\
2014\end{array}$ & $\begin{array}{l}\text { Parents of chil- } \\
\text { dren aged 12-14 } \\
\text { months }\end{array}$ & $\begin{array}{l}\text { Participants were } \\
\text { sent either a plain } \\
\text { text message } \\
\text { (SMS) or a text } \\
\text { message with pic- } \\
\text { tures once } 7-10 \\
\text { days before the } \\
\text { scheduled appoint- } \\
\text { ment date. Con- } \\
\text { trols were given a } \\
\text { verbal reminder. }\end{array}$ & $\begin{array}{l}\text { MMR vaccination } \\
\text { coverage rate } \\
\text { Timely vaccination } \\
\text { (difference between } \\
\text { scheduled date of } \\
\text { appointment visit } \\
\text { and actual date of } \\
\text { visit that the child } \\
\text { was brought in for } \\
\text { vaccination) }\end{array}$ & 75 parents & $\begin{array}{l}\text { Vaccination rates did not } \\
\text { differ between the } \\
\text { groups. } \\
\text { Compared with verbal } \\
\text { reminders, text reminders } \\
\text { were associated with } \\
\text { well-timed vaccination } \\
\text { (difference between } \\
\text { scheduled date of appoint- } \\
\text { ment and actual date of } \\
\text { vaccination), average de- } \\
\text { lay: } 0.96 \text { days for plain } \\
\text { text reminders, } 2.72 \text { days } \\
\text { for picture text re- } \\
\text { minders, and } 20.64 \text { days } \\
\text { for verbal reminders } \\
(P=.07)\end{array}$ \\
\hline \multirow[t]{3}{*}{$\begin{array}{l}\text { Crawford et al, } \\
2014 \text { [18] }\end{array}$} & \multirow[t]{3}{*}{$\begin{array}{l}\text { Balaka Dis- } \\
\text { trict, Malawi }\end{array}$} & \multirow[t]{3}{*}{$\begin{array}{l}2011- \\
2013\end{array}$} & \multirow[t]{3}{*}{$\begin{array}{l}\text { Mean age of } \\
\text { child: } 4 \text { months }\end{array}$} & \multirow[t]{3}{*}{$\begin{array}{l}\text { Health messages } \\
\text { (including vaccina- } \\
\text { tion reminders) de- } \\
\text { livered through } \\
\text { pushed SMS and } \\
\text { voice messages } \\
\text { sent to personal } \\
\text { phones and voice } \\
\text { messages retrieved } \\
\text { from a community } \\
\text { phone. }\end{array}$} & \multirow[t]{3}{*}{$\begin{array}{l}\text { Delivery success } \\
\text { rates for the three } \\
\text { delivery methods } \\
\text { User experience as- } \\
\text { sessed by phone sur- } \\
\text { vey: Acceptability, } \\
\text { comprehension, and } \\
\text { self-reported behav- } \\
\text { ior change. }\end{array}$} & \multirow[t]{3}{*}{$\begin{array}{l}2611 \text { caregivers } \\
\text { of children. A } \\
\text { total of } 1137 \\
\text { caregivers re- } \\
\text { sponded to the } \\
\text { phone survey. }\end{array}$} & $\begin{array}{l}\text { Choice of delivery sys- } \\
\text { tem: retrieved voice mes- } \\
\text { saging } 63.35 \% \\
(1654 / 2611) \text {; Pushed } \\
\text { SMS } 28.07 \%(733 / 2611) \text {; } \\
\text { Pushed voice message } \\
8.58 \%(224 / 2611) \\
\text { Delivery success: Pushed } \\
\text { SMS } 64.10 \% \\
(13,053 / 20,363) \text {; Pushed } \\
\text { voice } 53.81 \% \\
(1515 / 2815) ; \text { Retrieved } \\
\text { voice } 27.36 \% \\
(14,455 / 52,829) \text {. }\end{array}$ \\
\hline & & & & & & & $\begin{array}{l}\text { Phone survey results: } \\
22.6 \%(51 / 226) \text { reported } \\
\text { not receiving any mes- } \\
\text { sages, most were pushed } \\
\text { voice enrollees. }\end{array}$ \\
\hline & & & & & & & $\begin{array}{l}98.9 \%(263 / 266) \text { trusted } \\
\text { messages they received; } \\
75.2 \%(200 / 266) \text { recalled } \\
\text { last message. Pushed } \\
\text { SMS enrollees were } \\
\text { more likely to report in- } \\
\text { tended or actual change } \\
\text { in behavior }(91 \%, 87 / 96) \\
\text { than pushed }(56 \%, \\
17 / 30,) \text { or retrieved } \\
(65.7 \%, 92 / 140,) \text { voice } \\
\text { enrollees; } P=.01 .\end{array}$ \\
\hline
\end{tabular}




\begin{tabular}{|c|c|c|c|c|c|}
\hline $\begin{array}{l}\text { Lead author, } \\
\text { date }\end{array}$ & Location & $\begin{array}{l}\text { Year } \\
\text { of } \\
\text { study }\end{array}$ & $\begin{array}{l}\text { Age range or } \\
\text { mean age }\end{array}$ & Intervention & Outcome evaluated \\
\hline $\begin{array}{l}\text { Kazi et al, } 2014 \\
{[19]}\end{array}$ & $\begin{array}{l}\text { Karachi, Pak- } \\
\text { istan }\end{array}$ & $\begin{array}{l}2012- \\
2013\end{array}$ & Not given (NG) & $\begin{array}{l}\text { SMS messages } \\
\text { sent to caregivers } \\
\text { to monitor cover- } \\
\text { age of polio supple- } \\
\text { mentary immuniza- } \\
\text { tion activities } \\
\text { (SIAs): } \\
\text { 1. Did the vaccina- } \\
\text { tor visit your } \\
\text { home? } \\
2 . \text { Did [child] re- } \\
\text { ceive polio vac- } \\
\text { cine? } \\
\text { US } \$ 0.20 \text { of phone } \\
\text { credit was given } \\
\text { for replying. Nonre- } \\
\text { sponders were con- } \\
\text { tacted via direct } \\
\text { phone calls. }\end{array}$ & $\begin{array}{l}\text { Proportion of care- } \\
\text { givers who replied } \\
\text { to the SMS or fol- } \\
\text { low-up phone calls. } \\
\text { Estimates of vaccine } \\
\text { coverage achieved } \\
\text { during polio SIAs } \\
\text { obtained through au- } \\
\text { tomated SMS and } \\
\text { currently used meth- } \\
\text { ods for estimating } \\
\text { vaccine coverage, as } \\
\text { utilized by the } \\
\text { World Health Orga- } \\
\text { nization. }\end{array}$ \\
\hline
\end{tabular}

\begin{tabular}{|c|c|c|c|c|c|}
\hline $\begin{array}{l}\text { Wakadha et al, } \\
2013 \text { [20] }\end{array}$ & $\begin{array}{l}30 \text { villages } \\
\text { within } 5 \mathrm{~km} \text { of } \\
\text { Ting'Wan'I } \\
\text { hospital in } \\
\text { Western } \\
\text { Kenya. }\end{array}$ & 2011 & $\begin{array}{l}\text { Mothers of chil- } \\
\text { dren up to } 4 \\
\text { weeks of age at } \\
\text { baseline }\end{array}$ & $\begin{array}{l}\text { Reminder SMS } \\
\text { sent ( } 3 \text { days prior } \\
\text { and on day of vac- } \\
\text { cination) for } 2 \text { dos- } \\
\text { es of pentavalent } \\
\text { vaccination. If the } \\
\text { child was vaccinat- } \\
\text { ed on time, the } \\
\text { mother was given } \\
\text { approximately US } \\
\$ 2 \text {. If the child was } \\
\text { not vaccinated, an- } \\
\text { other reminder was } \\
\text { sent. }\end{array}$ & $\begin{array}{l}\text { (1) Percentage of } \\
\text { children vaccinated } \\
\text { at hospital or other } \\
\text { health facilities. } \\
\text { (2) Percentage who } \\
\text { did not receive } \\
\text { SMSs } \\
\text { (3) Percentage with } \\
\text { mobile phone access } \\
\text { 4) Follow-up at } 14 \\
\text { weeks: influence of } \\
\text { financial reward on } \\
\text { vaccination }\end{array}$ \\
\hline
\end{tabular}

Touray et al, 10 states in 2012- NG

2016 [21] northern Nige- 2015

ria
Global positioning Settlements covered NG

system-enabled by vaccination teams

Android phones during polio cam-

were given to vacci- paigns

nation teams and

were used to

record team tracks.
72 mothers

(first dose: 69

sent SMS re-

minders, 3 not

sent, second

dose: 44 sent

SMS)
Across 7 dis- Response rate: first SMS (823/5880).

$74.90 \%(4404 / 5880)$ of participants did not respond to SMS messages, of whom, $56.00 \%$ (2466/4404) responded to an investigator's phone calls. Those who responded to calls had similar levels of vaccine coverage to those who responded to SMSs.

Reasons given for not responding to SMS (of caregivers who were contactable by direct phone call): "Too busy" $36.01 \%$ (888/2466); "Not interested" $32.00 \%$ (789/2466); "Unable to read the message" $20.00 \%(493 / 2466)$.

(1) First dose: $70 \%$ (48/69) vaccinated at Ting'wang'I, Hospital, $10 \%(7 / 69)$ at other hospitals. Second dose: $91 \%$ (40/44) vaccinated at TWI hospital, 5\% (2/44) at other hospitals.

(2) Of the $38 \%$ (27/72) not sent SMS, $26 \%$ (7/27) vaccinated at TWI, $19 \%(5 / 27)$ at other hospitals, 30\% (8/27) not vaccinated, and $26 \%(7 / 27)$ unknown.

(3) $26 \%(19 / 72)$ had their own phone, and $74 \%$ (53/72) had access to another person's phone

(4) Forty-nine mothers reported reminders influenced their decision to vaccinate.

There was a reduction in chronically missed settlements (those missed in the last 3 campaigns): 2014-5833 settlements, 2015-1257 settlements.

There was an increase in the number of missed settlements: 2014 -4142, 2015-7008. 


\begin{tabular}{|c|c|c|c|c|c|}
\hline $\begin{array}{l}\text { Lead author, } \\
\text { date }\end{array}$ & Location & $\begin{array}{l}\text { Year } \\
\text { of } \\
\text { study }\end{array}$ & $\begin{array}{l}\text { Age range or } \\
\text { mean age }\end{array}$ & Intervention & Outcome evaluated \\
\hline $\begin{array}{l}\text { Balakrishnan et } \\
\text { al, } 2016 \text { [22] }\end{array}$ & Bihar, India & $\begin{array}{l}2012- \\
2014\end{array}$ & $\mathrm{NG}$ & $\begin{array}{l}\text { Mobile-based tool } \\
\text { for health workers } \\
\text { that registers when } \\
\text { vaccinations are } \\
\text { due and adminis- } \\
\text { tered, creating } \\
\text { electronic records. }\end{array}$ & $\begin{array}{l}\text { Received } 1+\text { tetanus } \\
\text { vaccine }\end{array}$ \\
\hline
\end{tabular}

Number of par- Results

ticipants

512 frontline Coverage in implementaworkers, 19,888 tion area $(95 \% \mathrm{CI})$ : children regis- $\quad 79.38 \%$ (58.90-80.26) tered $\quad(15,771$ children vaccinated of 19,888 registered)

Coverage in implementation area in the previous year (\%): 74.12

Coverage in rest of Bihar (\%): 80

\begin{tabular}{|c|c|c|c|c|c|c|c|}
\hline $\begin{array}{l}\text { Mbabazi et al, } \\
2015 \text { [23] }\end{array}$ & $\begin{array}{l}\text { Kenya: } 8 \text { dis- } \\
\text { tricts of Nairo- } \\
\text { bi and } 3 \text { from } \\
\text { Nyanza or } \\
\text { western } \\
\text { provinces }\end{array}$ & 2012 & $\begin{array}{l}\text { Children aged } \\
\text { 9-59 months }\end{array}$ & $\begin{array}{l}\text { A Web-enabled } \\
\text { mobile phone app } \\
\text { recording house } \\
\text { visits ( } 3 \text { days prior } \\
\text { and } 4 \text { days after } \\
\text { vaccination cam- } \\
\text { paigns), vaccina- } \\
\text { tions, and relaying } \\
\text { information to } \\
\text { campaign organiz- } \\
\text { ers. }\end{array}$ & $\begin{array}{l}\text { Percentage of house- } \\
\text { holds aware of the } \\
\text { campaign before } \\
\text { start; Percentage } \\
\text { planning to vacci- } \\
\text { nate their children } \\
\text { Post campaign: Per- } \\
\text { centage of house- } \\
\text { holds with children } \\
\text { vaccinated against } \\
\text { measles; Percentage } \\
\text { with a confirmed } \\
\text { vaccination. }\end{array}$ & $\begin{array}{l}164,643 \text { houses } \\
\text { ( } 161,695 \text { chil- } \\
\text { dren) pre cam- } \\
\text { paign; } 175,617 \\
\text { houses ( } 180,493 \\
\text { children) post } \\
\text { campaign }\end{array}$ & $\begin{array}{l}56.00 \%(92,200 / 164,643) \\
\text { of households had heard } \\
\text { about the campaign. } \\
75.00 \% \\
(123,482 / 164,643) \text { of } \\
\text { households planned to } \\
\text { bring their children for } \\
\text { vaccination. } \\
96.00 \%(168, \\
592 / 175,617) \text { of house- } \\
\text { holds reported children } \\
\text { having had a measles } \\
\text { vaccination post cam- } \\
\text { paign, and } 92.00 \% \\
(161,568 / 175,617) \text { of } \\
\text { households had children } \\
\text { with a confirmed vaccina- } \\
\text { tion. }\end{array}$ \\
\hline
\end{tabular}

Eleven initiatives were identified from gray and white literature; eight took place in India, two in Pakistan, and one in Zambia. Several programs involved more than one intervention, including messages sent to parents to encourage their children to get vaccinated, information about vaccination made freely accessible via mobile phone, tools to identify unvaccinated children with the health authority using SMS, data management tools for health workers (such as electronic vaccination records and a mobile phone app to track where vaccinations have been administered and control supplies), and tools to help health workers persuade hesitant families.

\section{SMS Reminders for Vaccinations}

Eight peer-reviewed studies reported the use of phone calls or SMS reminders for vaccinations, two of which additionally offered cash incentives. The three studies that did not offer cash incentives included an RCT by Bangure et al [14] conducted in Zimbabwe. SMS reminders were sent to parents $(n=152)$ when their baby was 6,10 , and 14 weeks old, in addition to routine health education. The control group received health education alone $(n=152)$. At all three time points, the percentage of children fully vaccinated with the relevant dose of polio, pentavalent, and pneumococcal vaccines was significantly higher in the intervention than the control group (<.001), and the delay in receiving the vaccinations was significantly less in the intervention than the control group (<.001). Another RCT by
Brown et al [15] conducted in Nigeria identified increased coverage rates relative to the usual care when receiving phone call reminders 2 days and 1 day before a vaccination appointment (Relative risk 1.72, 95\% CI 1.50-1.98). Uddin et al [16] similarly found that SMS reminders increased the odds of vaccination uptake in both urban and rural areas; odds ratio (OR) 2.3 (95\% CI 1.1-5.5) and OR 3.6 (95\% CI 1.5-8.9), respectively. Garcia-Dia et al [17] assessed coverage rates in an RCT in the Philippines after 75 parents were sent either a plain text message (short service message, SMS), a text message with pictures, or a verbal reminder. Although vaccination rates did not differ by reminder, text reminders with and without a picture were associated with a shorter delay in receiving the vaccination than verbal reminders. Crawford et al [18] sent SMS or voice messages to either the personal or community phone of 2611 caregivers of children under the age of 1 year. Pushed SMS messaging (where a message is sent to a phone's notification center or status bar) was the most successful mode of delivery $(64.10 \%, 13,053 / 20,363$, of sent messages were received). However, most women did not own a mobile phone, so similar numbers of messages were delivered by retrieved voicemail to community phones and pushed SMS to personal phones. No control group was included, but the majority of individuals who received messages trusted $(98.8 \%$; 263/266) and could recall $(72.2 \%$; 200/277) those messages. 
Table 2. Summary of studies from white and gray literature.

\begin{tabular}{|c|c|c|c|c|c|c|c|c|}
\hline $\begin{array}{l}\text { Name of study or } \\
\text { source of partici- } \\
\text { pants }\end{array}$ & Location & $\begin{array}{l}\text { Year of } \\
\text { study }\end{array}$ & $\begin{array}{l}\text { Age } \\
\text { range or } \\
\text { mean age }\end{array}$ & Intervention form & $\begin{array}{l}\text { Intervention pe- } \\
\text { riod and regular- } \\
\text { ity of interven- } \\
\text { tion }\end{array}$ & $\begin{array}{l}\text { Outcome evaluat- } \\
\text { ed }\end{array}$ & $\begin{array}{l}\text { Total number } \\
\text { of participants }\end{array}$ & Results \\
\hline $\begin{array}{l}\text { MIRA channel } \\
\text { [24] }\end{array}$ & $\begin{array}{l}\text { Haryana, } \\
\text { India }\end{array}$ & $\begin{array}{l}\text { 2012-on- } \\
\text { going }\end{array}$ & Children & $\begin{array}{l}\text { Integrated mobile } \\
\text { phone channel } \\
\text { with health infor- } \\
\text { mation to women } \\
\text { and connecting } \\
\text { them with health } \\
\text { services. }\end{array}$ & Continuous & Vaccination rates & $\begin{array}{l}\text { Not given } \\
\text { (NG) }\end{array}$ & $\begin{array}{l}\text { Increase in vacci- } \\
\text { nation rates by } \\
41 \% \text { (from } 51 \% \\
\text { to } 92 \% \text {, overall } \\
\text { rates in Haryana: } \\
78 \% \text { ). }\end{array}$ \\
\hline Mobile Kunji [25] & $\begin{array}{l}\text { Bihar, In- } \\
\text { dia }\end{array}$ & $\begin{array}{l}2011- \\
2015\end{array}$ & $\mathrm{NG}$ & $\begin{array}{l}\text { When a health } \\
\text { worker dials the } \\
\text { number, they can } \\
\text { play a health } \\
\text { message-voiced } \\
\text { by a character } \\
\text { called Dr Anita, } \\
\text { an engaging but } \\
\text { authoritative fe- } \\
\text { male doctor-to } \\
\text { the family via } \\
\text { their mobile } \\
\text { phone. }\end{array}$ & NG & $\begin{array}{l}\text { Percentage of } \\
\text { children unvacci- } \\
\text { nated, Percentage } \\
\text { of children (6-11 } \\
\text { months) receiv- } \\
\text { ing DPT2 (diph- } \\
\text { theria) vaccine, } \\
\text { Percentage of } \\
\text { children (<11 } \\
\text { months) with a } \\
\text { vaccination card }\end{array}$ & NG & $\begin{array}{l}\text { Mobile Kunji } \\
\text { was not found to } \\
\text { significantly alter } \\
\text { vaccination up- } \\
\text { take [26]. }\end{array}$ \\
\hline $\begin{array}{l}\text { UNICEF, India's } \\
\text { National Immuniza- } \\
\text { tion Day [27] }\end{array}$ & India & $\begin{array}{l}1999- \\
2000\end{array}$ & Children & $\begin{array}{l}\text { India's national } \\
\text { telecom authority } \\
\text { agreed to replace } \\
\text { the ringtone with } \\
\text { a recorded mes- } \\
\text { sage reminding } \\
\text { the public about } \\
\text { the date of the } \\
\text { National Immu- } \\
\text { nization Day. }\end{array}$ & Annually & $\begin{array}{l}\text { Number of chil- } \\
\text { dren vaccinated } \\
\text { for polio, Percent- } \\
\text { age of coverage } \\
(2+\text { doses }) \text {, Per- } \\
\text { centage of zero } \\
\text { doses, number of } \\
\text { polio cases }\end{array}$ & NG & $\begin{array}{l}151 \text { million chil- } \\
\text { dren vaccinated, } \\
98.6 \% \text { coverage } \\
\text { (at least } 2 \text { doses), } \\
0.7 \% \text { of children } \\
\text { with zero doses, } \\
265 \text { cases of po- } \\
\text { lio in } 2000 .\end{array}$ \\
\hline Mobilink [28,29] & Pakistan & $\begin{array}{l}2009- \\
2012\end{array}$ & Children & $\begin{array}{l}\text { Subscribers to the } \\
\text { Mobilink mobile } \\
\text { operator will be } \\
\text { able to report ar- } \\
\text { eas and children } \\
\text { where the polio } \\
\text { vaccination teams } \\
\text { have not reached. } \\
\text { The respective } \\
\text { health authority } \\
\text { will then be in } \\
\text { contact to vacci- } \\
\text { nate the missed } \\
\text { children. Mo- } \\
\text { bilink also sends } \\
\text { an SMS to create } \\
\text { awareness about } \\
\text { polio. }\end{array}$ & $\begin{array}{l}\text { Period: } 1-3 \\
\text { days, with }>3 \\
\text { rounds for re- } \\
\text { porting unvacci- } \\
\text { nated children. }\end{array}$ & $\mathrm{NG}$ & $\mathrm{NG}$ & $\begin{array}{l}15,000 \text { SMS mes- } \\
\text { sages about un- } \\
\text { vaccinated chil- } \\
\text { dren were re- } \\
\text { ceived during } \\
\text { February } 15-17 \text {, } \\
2010 .\end{array}$ \\
\hline Aarogyam [30] & $\begin{array}{l}\text { Uttar } \\
\text { Pradesh, } \\
\text { India }\end{array}$ & $\begin{array}{l}2008 \text { on- } \\
\text { wards }\end{array}$ & $\begin{array}{l}\text { Children } \\
\text { under } 5 \\
\text { years }\end{array}$ & $\begin{array}{l}\text { Health alerts are } \\
\text { sent to parents } \\
\text { about vaccination } \\
\text { through an SMS } \\
\text { and phone calls. }\end{array}$ & NG & $\begin{array}{l}\text { Vaccination cov- } \\
\text { erage }\end{array}$ & $\mathrm{NG}$ & $\begin{array}{l}\text { Vaccination cov- } \\
\text { erage has shown } \\
\text { a significant posi- } \\
\text { tive trend over } \\
\text { time. Polio, } \\
\text { Bacillus Cal- } \\
\text { mette-Guérin } \\
\text { (BCG), measles, } \\
\text { and tetanus cover- } \\
\text { age has gone up } \\
\text { from approximate- } \\
\text { ly } 60 \% \text { in } 2008 \text { to } \\
91 \% \text { in } 2010 .\end{array}$ \\
\hline
\end{tabular}




\begin{tabular}{|c|c|c|c|c|c|c|c|c|}
\hline $\begin{array}{l}\text { Name of study or } \\
\text { source of partici- } \\
\text { pants }\end{array}$ & Location & $\begin{array}{l}\text { Year of } \\
\text { study }\end{array}$ & $\begin{array}{l}\text { Age } \\
\text { range or } \\
\text { mean age }\end{array}$ & Intervention form & $\begin{array}{l}\text { Intervention pe- } \\
\text { riod and regular- } \\
\text { ity of interven- } \\
\text { tion }\end{array}$ & $\begin{array}{l}\text { Outcome evaluat- } \\
\text { ed }\end{array}$ & $\begin{array}{l}\text { Total number } \\
\text { of participants }\end{array}$ & Results \\
\hline Khushi Baby [31] & $\begin{array}{l}\text { Northern } \\
\text { India }\end{array}$ & 2015 & Infants & $\begin{array}{l}\text { Electronic copy } \\
\text { of the vaccination } \\
\text { record stored on } \\
\text { a necklace. } \\
\text { Health workers } \\
\text { scan the necklace } \\
\text { using an app on } \\
\text { their mobile } \\
\text { phone to transfer } \\
\text { vaccination data } \\
\text { to the necklace. } \\
\text { Data are also auto- } \\
\text { matically upload- } \\
\text { ed to "the cloud." } \\
\text { Parents get vacci- } \\
\text { nation reminder } \\
\text { voice calls. }\end{array}$ & Continuous & NG & NG & $\begin{array}{l}\text { Pilot study is on- } \\
\text { going. }\end{array}$ \\
\hline mSakhi [32] & $\begin{array}{l}\text { Uttar } \\
\text { Pradesh, } \\
\text { India }\end{array}$ & 2011 & NG & $\begin{array}{l}\text { A mobile-based } \\
\text { interactive multi- } \\
\text { media learning } \\
\text { app for health } \\
\text { workers. }\end{array}$ & 4 months & $\begin{array}{l}\text { Increase in } \\
\text { knowledge in } \\
\text { maternal-new- } \\
\text { born care (includ- } \\
\text { ing vaccination) }\end{array}$ & $\begin{array}{l}25 \text { health visi- } \\
\text { tors }\end{array}$ & $\begin{array}{l}\text { Qualitative data } \\
\text { indicated im- } \\
\text { proved counsel- } \\
\text { ing during home } \\
\text { visits and in- } \\
\text { creased credibili- } \\
\text { ty of health work- } \\
\text { ers in the commu- } \\
\text { nity. }\end{array}$ \\
\hline HealthPhone [33] & India & $\begin{array}{l}\text { 2009-on- } \\
\text { going }\end{array}$ & Children & $\begin{array}{l}\text { Video reference } \\
\text { library that cov- } \\
\text { ers vaccination } \\
\text { and SMS mes- } \\
\text { sages for those } \\
\text { who cannot ac- } \\
\text { cess video. }\end{array}$ & $\begin{array}{l}\text { No time limit, } \\
\text { continuous }\end{array}$ & $\begin{array}{l}\text { Multiple health } \\
\text { outcomes, includ- } \\
\text { ing uptake of } \\
\text { vaccines }\end{array}$ & NG & $\begin{array}{l}\text { "After we put } \\
\text { HealthPhone into } \\
\text { the hands of vil- } \\
\text { lage wom- } \\
\text { en...their health } \\
\text { and the health of } \\
\text { their children } \\
\text { dramatically im- } \\
\text { proved." }\end{array}$ \\
\hline Freedom Polio [34] & India & 2012 & $\begin{array}{l}\text { Children } \\
\text { under } 5 \\
\text { years }\end{array}$ & $\begin{array}{l}\text { An app that al- } \\
\text { lows health } \\
\text { works to track } \\
\text { where polio vacci- } \\
\text { nations have been } \\
\text { administered. }\end{array}$ & $\begin{array}{l}\text { No time limit, } \\
\text { continuous }\end{array}$ & NG & $\begin{array}{l}21 \text { million } \\
\text { children }\end{array}$ & NG \\
\hline $\begin{array}{l}\text { UNICEF, Zambian } \\
\text { Health Ministry, } \\
\text { two mobile phone } \\
\text { companies, Zain } \\
\text { and Mobile Tele- } \\
\text { phone Networks } \\
\text { [35] }\end{array}$ & $\begin{array}{l}28 \text { districts } \\
\text { in Zambia }\end{array}$ & 2009 & $\begin{array}{l}\text { Children } \\
\text { under } 5 \\
\text { years }\end{array}$ & $\begin{array}{l}\text { SMS: "Your } \\
\text { child can be } \\
\text { healthier! Take } \\
\text { your children un- } \\
\text { der age five to } \\
\text { the nearest health } \\
\text { centre for free } \\
\text { vaccinations from } \\
\text { 20-25 July." }\end{array}$ & NG & NG & $\mathrm{NG}$ & $\mathrm{NG}$ \\
\hline $\begin{array}{l}\text { Interactive Re- } \\
\text { search and Devel- } \\
\text { opment's (IRD) In- } \\
\text { teractive alerts } \\
{[36,37]}\end{array}$ & $\begin{array}{l}\text { Karachi, } \\
\text { Pakistan }\end{array}$ & $\begin{array}{l}2012 \text { on- } \\
\text { wards }\end{array}$ & $\mathrm{NG}$ & $\begin{array}{l}\text { Mobile } \\
\text { phone-based vac- } \\
\text { cine registry sys- } \\
\text { tem that uses } \\
\text { SMS reminders } \\
\text { to caregivers and } \\
\text { conditional cash } \\
\text { transfers to care- } \\
\text { givers and health } \\
\text { workers. }\end{array}$ & NG & $\begin{array}{l}\text { Vaccination cov- } \\
\text { erage and timeli- } \\
\text { ness }\end{array}$ & 14,000 infants & $\begin{array}{l}\text { Interim data anal- } \\
\text { ysis suggests im- } \\
\text { proved immuniza- } \\
\text { tion coverage and } \\
\text { timeliness; an im- } \\
\text { pact evaluation } \\
\text { study is under- } \\
\text { way to assess this } \\
\text { more thoroughly. }\end{array}$ \\
\hline
\end{tabular}


Table 3. Geographical locations of the included studies.

\begin{tabular}{ll}
\hline Location & Number of studies included \\
\hline Bangladesh & 1 \\
India & 9 \\
Kenya & 2 \\
Malawi & 1 \\
Nigeria & 2 \\
Pakistan & 3 \\
The Philippines & 1 \\
Zambia & 1 \\
Zimbabwe & 1 \\
\hline
\end{tabular}

\section{Cash Incentives to Increase Vaccination Uptake}

Two studies used cash incentives to increase vaccination uptake while sending SMS reminders. Kazi et al [19] used SMS messages sent to 5880 caregivers in Pakistan, along with a conditional cash transfer in the form of approximately US $\$ 0.20$ of phone credit, to monitor polio vaccination coverage. Response rates to the SMS messages were low $(74.90 \%$, 4404/5880, of participants did not respond). The initial nonresponders who were followed up by phone call had similar rates of vaccination uptake to those who responded to the SMS messages. Wakadha et al [20] conducted a pilot study exploring the feasibility of setting up an integrated mobile phone-based system to remind and incentivize mothers $(n=72)$ to vaccinate their children in rural Kenya. Mothers received SMS reminders of vaccination dates and conditional cash transfers of either mPESA (a mobile-based money transfer service) credit or phone credit, if the child was vaccinated within 4 weeks of the scheduled date. The small sample size and lack of a comparison group meant that it was not possible to draw conclusions about the program's effectiveness, but enrolled mothers reported mostly positive experiences at the end of the study, and most mothers did have access to a phone. Importantly, this study was limited by its focus on a single facility. Caregivers who took children to nearby facilities for vaccinations were recorded as unvaccinated by the first facility and thereafter, were not sent additional SMS.

\section{Mobile-Based Interactive Apps for Health Workers}

Three studies used mobile-based interactive learning apps to aid or track the progress of health workers in vaccination. Touray et al [21] utilized the global positioning system of Android phones to track where vaccination teams had been, which helped reduce the number of settlements in northern
Nigeria that were not covered in the last three campaigns from 5833 in 2014 to 1257 in 2015. Balakrishnan et al [22] found no improvement in coverage for tetanus when health workers used a mobile phone tool that created electronic vaccination records and registered when vaccination was due and administered. Mbabazi et al [23] evaluated a mobile phone app used by health workers that was designed to assess the awareness and intention to take part in a measles vaccination campaign before the campaign's onset at house visits, as well as to evaluate the uptake of the vaccinations after the campaign. Of the more than 150,000 households included in the survey, approximately half were aware of the vaccination campaign, and once informed, $74.99 \%(123,482 / 164,643)$ of households planned to bring their children in for vaccination. After the campaign, $95.99 \%$ $(168,592 / 175,617)$ of households reported their child had received a measles vaccination, and $92.00 \%$ (161, 568 of $175,617)$ had this independently confirmed. This intervention was found to reduce misconceptions about vaccination, and the use of the mobile phone app to assess uptake of vaccination helped inform service delivery plans.

\section{Risk of Bias}

Of the 10 peer-reviewed studies, three studies did not evaluate controls or individuals unexposed to the intervention, so it was not possible to evaluate their risk of bias using the Newcastle-Ottawa Scale or the Cochrane Collaboration tool. In the eight studies that could be evaluated, the risk of selection bias affecting the results was judged to be low for one RCT by Bangure et al but with a higher risk of bias in the other two RCTs (Table 4). The risk of bias in the observational studies was also deemed to be high, with most of the concern regarding the possibility of outcome bias and bias arising from a lack of comparability (Table 5). 
Table 4. Assessment of bias in randomized controlled trials.

\begin{tabular}{|c|c|c|c|c|c|c|c|}
\hline \multirow[t]{2}{*}{ Paper } & \multicolumn{7}{|l|}{ Risk of bias } \\
\hline & $\begin{array}{l}\text { Random sequence } \\
\text { generation }\end{array}$ & $\begin{array}{l}\text { Allocation conceal- } \\
\text { ment }\end{array}$ & $\begin{array}{l}\text { Blinding of partici- } \\
\text { pants and personnel }\end{array}$ & $\begin{array}{l}\text { Blinding of outcome } \\
\text { assessment }\end{array}$ & $\begin{array}{l}\text { Incomplete out- } \\
\text { come data }\end{array}$ & $\begin{array}{l}\text { Selective re- } \\
\text { porting }\end{array}$ & $\begin{array}{l}\text { Other } \\
\text { bias }\end{array}$ \\
\hline $\begin{array}{l}\text { Bangure et al } \\
{[14]}\end{array}$ & Low & Low & Unclear & Unclear & Low & Low & Low \\
\hline $\begin{array}{l}\text { Brown et al } \\
{[15]}\end{array}$ & Low & Low & High & Medium & Low & Low & Low \\
\hline $\begin{array}{l}\text { Garcia-Dia et al } \\
{[17]}\end{array}$ & Low & Medium & High & Unclear & Low & Low & Low \\
\hline
\end{tabular}

Table 5. Assessment of bias in observational cohort studies.

\begin{tabular}{llll}
\hline Paper & Selection & & Comparability $^{\mathrm{b}}$ \\
\hline Uddin et al [16] & 2 & 2 & Outcome or exposure $^{\mathrm{c}}$ \\
Wakadha et al [20] & 4 & 0 & 1 \\
Touray et al [21] & 3 & 0 & 3 \\
Balakrishnan et al [22] & 2 & 0 & 1 \\
\hline
\end{tabular}

${ }^{\mathrm{a}}$ Maximum score is 4.

${ }^{\mathrm{b}}$ Maximum score is 2 .

${ }^{\mathrm{c}}$ Maximum score is 3 .

\section{Initiatives Identified From White and Gray Literature}

Of the eleven initiatives identified, six showed some evidence of impact on vaccination rates. Implementation of the MIRA channel [24] (an integrated mobile phone channel providing health information to women and connecting them with health services) corresponded with a $41 \%$ increase in vaccination rates. A program using the Mobile Kunji program [25,26] (in which the health worker can play a health message to the family via their mobile phone) recorded a 5\% decrease in the percentage of children (6-11 months) unvaccinated with the first diphtheria vaccine and a $6 \%$ increase in children receiving the second diphtheria vaccine. Another successful strategy included the involvement of India's national telecom authority who replaced the dial tone on mobile phones with a recorded message that reminded the public of National Immunization Day [27], whereas the Mobilink mobile operator in Pakistan recorded 13,000 SMS messages about unvaccinated children during the annual polio vaccination campaign in 2010 and circulated seven million SMS reminders in 2009 [28,29]. Aarogyam [30] reported improved vaccination uptake through the use of automatic voice calls and SMS reminders sent to parents about vaccination appointments, among other postnatal care.

Unfortunately, other initiatives did not provide quantitative results. Some pilot studies are ongoing (Khushi Baby [31]), and one provided qualitative evidence of improved knowledge [32]. No outcomes were found for three studies, one study used educational videos accessible on mobile phones [33], another looked at an app to track vaccinations [34], and two studies used SMS vaccination reminders [35-37].

\section{Discussion}

Overall, mHealth technology can and has been used to increase vaccination uptake in LMIC, but the quality of the evidence is limited, and further research is needed to better quantify its potential impact and to determine the most effective strategies.

\section{Evidence That mHealth Interventions Can be Effective in Increasing Vaccination Uptake}

The literature reviewed indicates that mobile technology can be used in a variety of ways to improve vaccination uptake. Although most studies lacked comparison groups, the results broadly suggest an improved uptake of vaccinations with mobile phone-based interventions.

SMS reminders for vaccination appointments were found to increase uptake and reduce delays in receiving vaccinations in Zimbabwe [14]. In Kenya, mothers who received SMS reminders about vaccination appointments reported mostly positive experiences [23]. A decrease in the percentage of unvaccinated children and an increase in the number of children with a vaccination card were found when health care workers used their mobile phones to play a prerecorded message to families. Furthermore, a $41 \%$ increase in vaccination rates was observed in rural India after the introduction of an integrated mobile channel providing health information and connecting mothers with health services [24].

However, some studies reported no improvement upon intervention. A study from Pakistan found low response rates to SMS messages about vaccinations, even when a financial reward was attached [19]. 


\section{Challenges in the Use of mHealth Interventions to Increase Vaccination Uptake}

The studies we reviewed, as well as the related research that these studies cited to explain the design of their interventions, raise a number of challenges that can impede the integration of mobile phones into vaccination programs. Several of these studies discuss rates of phone ownership in their particular areas of intervention, including how these differ among men and women (Crawford et al, Uddin et al, and Kazi et al). In LMIC, generally, women are $21 \%$ less likely to own a mobile phone than men (increasing to $37 \%$ in Asia) [38]. As women are the primary caregivers to children, this may impact mHealth vaccination interventions. Furthermore, two-thirds of illiterate adults are women [39], which can further reduce the effectiveness of SMS messages. In households where the father owns the mobile phone, it is imperative that the father is engaged in the project, as exemplified in the study by Wakadha et al [20], where in a few cases husbands did not approve of the study.

Frequent exposure to SMS messages can result in the effectiveness of the message being weakened; in a different setting, Strandbygaard et al found that participants stopped reading reminder messages after a few weeks [40]. Therefore, the effectiveness of messages of different length and over time needs to be assessed when sending SMSs.

Developing the appropriate infrastructure [9] and ensuring adequate resources are available is important. Weaknesses in other areas of the health system may render mHealth interventions aiming to increase demand for services meaningless: mHealth can improve access to vaccines only as long as they remain consistently available from health centers [9]. Additionally, increasing demand for vaccination can have unintended consequences. One study reported that extensive and comprehensive communication campaigns for 15 new vaccines led to greater demand for vaccination in a number of LMIC. However, high demand resulted in vaccine shortages, which later thwarted the increased demand [41]. For this reason, policy makers and implementers of mHealth interventions to improve vaccination programs should be aware that eHealth interventions in general [42], and mHealth interventions in particular $[6,43]$ are deeply complex and context-dependent.

\section{Limitations, Opportunities, and Need for Further Research}

Of the literature reviewed, the included studies were predominantly observational studies that appraised process and usage output. These had various methodological limitations such as (1) sample selection based on convenience, without randomization; (2) small sample sizes; (3) lack of information on process validation, including recruitment type, response rate, and retention rate; and (4) no control groups. These limitations make the conclusions of the observational studies less secure. Given the potential of mHealth, RCTs in LMIC to determine the efficacy of using mHealth for vaccinations are needed.

It is clear that there are a number of gaps in the literature concerning this topic in the countries of interest. Relatively more compelling evidence exists for mHealth interventions addressing demand-side barriers to service uptake, whereas fewer evaluated interventions aim to boost immunization by strengthening health systems through data management, decision support, or provider training and education. This is a notable gap because reviews of why children go unvaccinated document not only highlight gaps in household knowledge and attitudes but also issues related to poor service quality and accessibility $[8,9]$. Moreover, there is reason to believe that this gap can be addressed because outside immunization programs, mHealth interventions have been widely used as strengthening tools for health systems [4]. For example, given that a study on stock tracking of malaria medications in Tanzania showed a 52\% reduction in medication stock-outs within 21 weeks of the induction of weekly SMS requesting stock counts [44], there is a precedent for the integration of mHealth into vaccination stock control.

\section{Conclusions}

There is reason to be optimistic regarding the potential for mobile phones to increase vaccination coverage in LMIC. Mobile technologies are flexible and widely available tools that can be utilized in myriad ways. This review provides evidence of potential effectiveness for SMS reminders to families regarding vaccination, as well as for educational tools for health workers.

However, the research is preliminary and limited. Further research is needed to determine the most effective mHealth interventions and to refine their use, for example, clarifying the optimal schedule of reminders for programs using SMS reminders of vaccination appointments. It will also be necessary to evaluate different mHealth interventions against each other, and against other potential programs, to examine their comparative cost-effectiveness at increasing vaccination coverage. mHealth interventions addressing vaccination stock-outs, cold storage, or other health systems strengthening challenges merit further study.

Overall, there is preliminary evidence to support the use of mHealth technology to increase vaccination coverage in LMIC. However, further research is needed to guide and improve the use of these technologies in the future and to strengthen the case for their cost-effectiveness.

\section{Acknowledgments}

CO screened titles and abstracts, constructed tables, and contributed to writing and amending of the manuscript. EB, SD, and CF screened titles and abstracts and contributed to writing and amending of the report. IH developed the concept and contributed to writing and amending of the report. The study was funded by the Medical Research Council, British Heart Foundation, and Homerton College, Cambridge. The nonprofit organization Medic Mobile helped to clarify the need for this study and helped the study authors to identify relevant gray literature. The student-run think tank Polygeia set up the commission with Medic Mobile and supported the authors. 


\section{Conflicts of Interest}

IH is a board member at Medic Mobile, for which he receives no compensation. Medic Mobile is a nonprofit organization that equips health workers with free and open source digital tools to strengthen global health programs. All authors declare no competing financial interests.

\section{Multimedia Appendix 1}

PRISMA 2009 checklist.

[PDF File (Adobe PDF File), 117KB-Multimedia Appendix 1]

\section{Multimedia Appendix 2}

MOOSE checklist.

[PDF File (Adobe PDF File), 73KB-Multimedia Appendix 2]

\section{Multimedia Appendix 3}

Search terms used to identify relevant published literature.

[PDF File (Adobe PDF File), 31KB-Multimedia Appendix 3]

\section{References}

1. Apps.who. 58th World Health Assembly URL: http://apps.who.int/gb/ebwha/pdf files/WHA58-REC1/english/ A58 2005 REC1-en.pdf [WebCite Cache ID 6oRxo3M2W]

2. Free C, Phillips G, Galli L, Watson L, Felix L, Edwards P, et al. The effectiveness of mobile-health technology-based health behaviour change or disease management interventions for health care consumers: a systematic review. PLoS Med 2013;10(1):e1001362 [FREE Full text] [doi: 10.1371/journal.pmed.1001362] [Medline: 23349621]

3. Free C, Phillips G, Watson L, Galli L, Felix L, Edwards P, et al. The effectiveness of mobile-health technologies to improve health care service delivery processes: a systematic review and meta-analysis. PLoS Med 2013 Jan;10(1):e1001363 [FREE Full text] [doi: 10.1371/journal.pmed.1001363] [Medline: 23458994]

4. Labrique AB, Vasudevan L, Kochi E, Fabricant R, Mehl G. mHealth innovations as health system strengthening tools: 12 common applications and a visual framework. Glob Health Sci Pract 2013 Aug;1(2):160-171 [FREE Full text] [doi: 10.9745/GHSP-D-13-00031] [Medline: 25276529]

5. Mahmud N, Rodriguez J, Nesbit J. A text message-based intervention to bridge the healthcare communication gap in the rural developing world. Technol Health Care 2010;18(2):137-144. [doi: 10.3233/THC-2010-0576] [Medline: 20495253]

6. Holeman I, Evans J, Kane D, Grant L, Pagliari C, Weller D. Mobile health for cancer in low to middle income countries: priorities for research and development. Eur J Cancer Care (Engl) 2014 Nov;23(6):750-756. [doi: 10.1111/ecc.12250] [Medline: 25324023]

7. WHO. Health Topics: Immunization URL: http://www.who.int/topics/immunization/en/ [accessed 2017-03-30] [WebCite Cache ID 6pL19zCOR]

8. WHO. Immunization coverage fact sheet URL: http://www.who.int/mediacentre/factsheets/fs378/en/[WebCite Cache ID $\underline{60 S 1 K G 3 N b}]$

9. Mechael P, Batavia H, Kaonga N, Searle S, Kwan A, Goldberger A, et al. Globalproblems-globalsolutions. Barriers and gaps affecting mHealth in low and middle income countries: policy white paper URL: http://www.

globalproblems-globalsolutions-files.org/pdfs/mHealth Barriers White Paper.pdf [accessed 2017-02-22] [WebCite Cache ID 6oSk7TPSa]

10. Comminit. Lessons learned from five country studies of communication support for polio eradication and routine URL: http://comminit.com/hiv-aids/content/ lessons-learned-five-country-studies-communication-support-polio-eradication-and-routine[WebCite Cache ID 6oS7OuvdD]

11. WHO. Global immunization data URL: http://www.who.int/immunization/monitoring surveillance/ global immunization data.pdf [accessed 2017-03-30] [WebCite Cache ID 6pLlEWnBw]

12. Higgins JP, Altman DG, Gøtzsche PC, Jüni P, Moher D, Oxman AD, Cochrane Bias Methods Group, Cochrane Statistical Methods Group. The Cochrane Collaboration's tool for assessing risk of bias in randomised trials. Br Med J 2011;343:d5928 [FREE Full text] [Medline: 22008217]

13. Wells GA, Shea B, O'Connell D, Peterson J, Welch V, Losos M, et al. Ohri. The Newcastle-Ottawa Scale (NOS) for assessing the quality of nonrandomised studies in meta-analyses URL: http://www.ohri.ca/programs/clinical epidemiology/ oxford.asp[WebCite Cache ID 6oS7kdgJv] 
14. Bangure D, Chirundu D, Gombe N, Marufu T, Mandozana G, Tshimanga M, et al. Effectiveness of SMS reminders on childhood immunization programme in Kadoma, Zimbabwe - a randomized controlled trial, 2013. BMC Public Health 2015 Feb 12;15:137 [FREE Full text] [doi: 10.1186/s12889-015-1470-6] [Medline: 25885862]

15. Brown VB, Oluwatosin OA, Akinyemi JO, Adeyemo AA. Effects of community health nurse-led intervention on childhood routine immunization completion in primary health care centers in Ibadan, Nigeria. J Community Health 2016 Apr;41(2):265-273. [doi: 10.1007/s10900-015-0092-3] [Medline: 26395786]

16. Uddin MJ, Shamsuzzaman M, Horng L, Labrique A, Vasudevan L, Zeller K, et al. Use of mobile phones for improving vaccination coverage among children living in rural hard-to-reach areas and urban streets of Bangladesh. Vaccine 2016 Jan 4;34(2):276-283. [doi: 10.1016/j.vaccine.2015.11.024] [Medline: 26647290]

17. Garcia-Dia MJ, Fitzpatrick JJ, Madigan EA, Peabody JW. Using text reminder to improve childhood immunization adherence in the Philippines. Comput Inform Nurs 2017;35(4):212-218. [doi: 10.1097/CIN.0000000000000307] [Medline: 27828815]

18. Crawford J, Larsen-Cooper E, Jezman Z, Cunningham SC, Bancroft E. SMS versus voice messaging to deliver MNCH communication in rural Malawi: assessment of delivery success and user experience. Glob Health Sci Pract 2014;2(1):35-46 [FREE Full text] [doi: 10.9745/GHSP-D-13-00155] [Medline: 25276561]

19. Kazi AM, Murtaza A, Khoja S, Zaidi AK, Ali SA. Monitoring polio supplementary immunization activities using an automated short text messaging system in Karachi, Pakistan. Bull World Health Organ 2014 Mar 1;92(3):220-225 [FREE Full text] [doi: 10.2471/BLT.13.122564] [Medline: 24700982]

20. Wakadha H, Chandir S, Were EV, Rubin A, Obor D, Levine OS, et al. The feasibility of using mobile-phone based SMS reminders and conditional cash transfers to improve timely immunization in rural Kenya. Vaccine 2013 Jan 30;31(6):987-993 [FREE Full text] [doi: 10.1016/j.vaccine.2012.11.093] [Medline: 23246258]

21. Touray K, Mkanda P, Tegegn S, Nsubuga P, Erbeto TB, Banda R, et al. Tracking vaccination teams during polio campaigns in northern Nigeria by use of geographic information system technology. J Infect Dis 2016;213(Suppl 3):S67-S72. [Medline: 26609004]

22. Balakrishnan R, Gopichandran V, Chaturvedi S, Chatterjee R, Mahapatra T, Chaudhuri I. Continuum of care services for maternal and child health using mobile technology - a health system strengthening strategy in low and middle income countries. BMC Med Inform Decis Mak 2016 Jul 07;16:84 [FREE Full text] [doi: 10.1186/s12911-016-0326-z] [Medline: $\underline{27387548]}$

23. Mbabazi WB, Tabu CW, Chemirmir C, Kisia J, Ali N, Corkum MG, et al. Innovations in communication technologies for measles supplemental immunization activities: lessons from Kenya measles vaccination campaign, November 2012. Health Policy Plan 2015 Jun;30(5):638-644 [FREE Full text] [doi: 10.1093/heapol/czu042] [Medline: 24920218]

24. Mirachannel. MIRA channel - women mobile lifeline channel URL: http://www.mirachannel.org/ [accessed 2017-02-21] [WebCite Cache ID 6oS7yERNm]

25. Rethink1000days. Mobile kunji?: shaping demand and practices URL: https://www.rethink1000days.org/programme-outputs/ mobile-kunji/ [accessed 2017-02-21] [WebCite Cache ID 6oS8jWvQU]

26. Chamberlain S. Mitpressjournals. A mobile guide toward better health: how mobile kunji is improving birth outcomes in Bihar, India URL: http://mitpressjournals.org/userimages/ContentEditor/1415302178306/ INNOVATIONS_DIGITAL-INCLUSION.pdf [accessed 2017-03-29] [WebCite Cache ID 6pKQA7m9s]

27. WHO. The use of mobile phones in polio eradication URL: http://www.who.int/bulletin/volumes/94/2/15-163683/en/ [accessed 2017-02-23] [WebCite Cache ID 6oUUSV7c2]

28. Pktelecomnews.blogspot. Mobilink concludes awareness drive URL: http://pktelecomnews.blogspot.co.uk/2010/07/ mobilink-concludes-awareness-drive.html [accessed 2017-02-23] [WebCite Cache ID 6oUPJTtzD]

29. Thefreelibrary. Seven million SMS disseminated to boost anti-polio drive URL: https://www.thefreelibrary.com/403.htm [accessed 2017-02-23] [WebCite Cache ID 6oUOovIyK]

30. Indiagovernance. Aarogyam URL: http://indiagovernance.gov.in/files/gkc oneworld aarogyam.pdf [accessed 2017-03-29] [WebCite Cache ID 6pKQiCgRj]

31. Khushibaby. URL: http://www.khushibaby.org/ [accessed 2017-02-21] [WebCite Cache ID 6oS9Yk92T]

32. Kumar A, Bora G, Jana L. Papers.eletsonline. mSakhi putting technology into the hands of community health workers URL: http://papers.eletsonline.com/2011/11/21/msakhi-putting-technology-in-the-hands-of-community-health-workers/ [accessed 2017-03-30] [WebCite Cache ID 6pLmW0v4e]

33. YouTube. HealthPhoneTM: how immunization protects: completing the immunization cycle protects children URL: https:/ /www.youtube.com/watch?v=Wr-RKyifFmI [accessed 2017-02-23] [WebCite Cache ID 6oUX74xdN]

34. Quraishi S. Freedompolio. Freedom Polio URL: http://www.freedompolio.org/ZMQ_FreedomPolio_Brochure.pdf [accessed 2017-02-23] [WebCite Cache ID 6oUM9Cf3I]

35. UN News Centre. UN. UNICEF uses text messages to spread the word about polio in Zambia URL: http://www.un.org/ apps/news/story.asp?NewsID=31517\#.WK1U1RKLQcg[WebCite Cache ID 6oSkkb0sA]

36. Chandir S, Zaidi A, Khowaja S, Gonzales F. Africanstrategies4health. Interactive alerts: improving vaccine coverage through small incentives URL: http://www.africanstrategies4health.org/uploads/1/3/5/3/13538666/interactive alerts. pdf[WebCite Cache ID 6pKQv0DGw] 
37. Zaidi A, Khowaja S. Apps.WHO. Small incentives improve vaccine coverage in Pakistan URL: http://apps.who.int/iris/ bitstream/10665/92806/1/WHO RHR 13.16 eng.pdf[WebCite Cache ID 6pKR4YFBo]

38. Cherieblairfoundation. Women and mobile: a global opportunity URL: http://www.cherieblairfoundation.org/ women-and-mobile-a-global-opportunity/ [accessed 2017-07-11] [WebCite Cache ID 6rsUsDuzD]

39. UNESCO. Literacy URL: http://www.unesco.org/new/en/education/themes/education-building-blocks/literacy/resources/ statistics [WebCite Cache ID 6oS8EEgiE]

40. Strandbygaard U, Thomsen SF, Backer V. A daily SMS reminder increases adherence to asthma treatment: a three-month follow-up study. Respir Med 2010 Feb;104(2):166-171 [FREE Full text] [doi: 10.1016/j.rmed.2009.10.003] [Medline: 19854632]

41. Comminit. Bottlenecks and breakthroughs: lessons learned from new vaccine introductions in low-resource countries, 2008 to 2013 URL: http://www.comminit.com/global/content/ bottlenecks-and-breakthroughs-lessons-learned-new-vaccine-introductions-low-resource-cou[WebCite Cache ID 6oS8WxE5A]

42. Black AD, Car J, Pagliari C, Anandan C, Cresswell K, Bokun T, et al. The impact of eHealth on the quality and safety of health care: a systematic overview. PLoS Med 2011 Jan;8(1):e1000387 [FREE Full text] [doi: 10.1371/journal.pmed.1000387] [Medline: 21267058]

43. PLOS Medicine Editors. A reality checkpoint for mobile health: three challenges to overcome. PLoS Med 2013;10(2):e1001395 [FREE Full text] [doi: 10.1371/journal.pmed.1001395] [Medline: 23468597]

44. Barrington J, Wereko-Brobby O, Ward P, Mwafongo W, Kungulwe S. SMS for Life: a pilot project to improve anti-malarial drug supply management in rural Tanzania using standard technology. Malar J 2010 Oct 27;9:298 [FREE Full text] [doi: 10.1186/1475-2875-9-298] [Medline: 20979633]

\author{
Abbreviations \\ eHealth: electronic health \\ LMIC: low- and middle-income countries \\ mHealth: mobile health \\ OR: odds ratio \\ RCT: randomized controlled trial
}

\author{
Edited by $G$ Eysenbach; submitted 30.03.17; peer-reviewed by J Crawford, P Kawale; comments to author 14.06.17; revised version \\ received 11.07.17; accepted 11.07.17; published 04.10.17 \\ Please cite as: \\ Oliver-Williams C, Brown E, Devereux S, Fairhead C, Holeman I \\ Using Mobile Phones to Improve Vaccination Uptake in 21 Low- and Middle-Income Countries: Systematic Review \\ JMIR Mhealth Uhealth 2017;5(10):e148 \\ URL: http://mhealth.jmir.org/2017/10/e148/ \\ doi: $10.2196 /$ mhealth.7792 \\ PMID: 28978495
}

(C) Clare Oliver-Williams, Elizabeth Brown, Sara Devereux, Cassandra Fairhead, Isaac Holeman. Originally published in JMIR Mhealth and Uhealth (http://mhealth.jmir.org), 04.10.2017. This is an open-access article distributed under the terms of the Creative Commons Attribution License (https://creativecommons.org/licenses/by/4.0/), which permits unrestricted use, distribution, and reproduction in any medium, provided the original work, first published in JMIR mhealth and uhealth, is properly cited. The complete bibliographic information, a link to the original publication on http://mhealth.jmir.org/, as well as this copyright and license information must be included. 